\title{
LINKAGE RELATIONS OF THE BLOOD GROUP GENES OF MAN
}

\author{
HELENE A. HOLT, JOAN S. THOMPSON, RUTH SANGER and R. R. RACE \\ Medical Research Council Blood Group Research Unit, Lister Institute, London
}

Received 12.xi.5I

Introduction.-The results to date are here given of a search for linkage between the genes for human blood groups, for phenyl thiocarbamide tasting and for sex. The calculations are based on 487 families with two or more children. The blood grouping tests were done between 1938 and 195 I by this Unit or by its parent, the Galton Laboratory Serum Unit, established by Professor R. A. Fisher, with the support of the Rockefeller Foundation. Many of the families have appeared in papers from the two Units, but with those groups alone recorded which were appropriate to the particular study.

The $u$ statistics of Fisher (1935a, 1935 $b$ ) have been applied to the pedigrees, which have been treated as "data for the double backcross". Thus, we have scored the "certain" families of Finney (1940) which fall into the "mating types" 20 and $2 \mathrm{I}$. Since these pedigrees can be analysed in so many ways, we hope that it may be possible to make available the complete collection, including one-child families.

The earlier families could of course be tested for relatively few characters and consequently contribute much less to the general amount of information than do the hundred or so families which have been tested for the nine blood group systems now known. The point may be laboured thus: five of the recent families, taken at random, afford a total $\kappa$ of 85 : had they been counted in 1939 for $A B O, M N, P$, P.T.C. and sex alone, the total $\kappa$ would have been 14 .

Conclusions.--Our results are shown in the table; they disclose no likely linkages though the amount of information in many of the comparisons is small enough to leave plenty of room for future detection. In making so many counts it is to be expected that some of them will by chance approach significance at the I in 20 level, and in two comparisons, that between $P$ and Duffy and that between Duffy and Kidd, $\mathrm{S}(\lambda)$ is just greater than $\mathrm{I} \cdot 64 \sqrt{\mathrm{S}(\kappa)}$. In both these counts information is small and addition of the "doubtful" families (Finney, 1940) makes $\mathrm{S}(\lambda)$ less than $\mathrm{r} \cdot 64 \sqrt{\mathrm{S}(\kappa)}$.

Discussion.-Our results, where they overlap, support the findings of previous workers. Many of the past investigations have been confined to the testing of pairs of sibs. The most numerous family blood group results which have been analysed for linkage are: 166 families tested 
Linkage scores of the "certain" families amongst the 487; the upper figure showing $S(\kappa)$, the lower $S(\lambda)$

\begin{tabular}{|c|c|c|c|c|c|c|c|c|c|c|}
\hline & P.'C. & Kidd & Duffy & Lexwis & Kell & Luth. & $R h$ & $P$ & $M N S$ & $A B O$ \\
\hline Sex & $\begin{array}{r}27 \\
-1\end{array}$ & $\begin{array}{r}22 \\
+4\end{array}$ & $\begin{array}{r}4^{8} \\
+4\end{array}$ & $\begin{array}{r}96 \\
-6\end{array}$ & $\begin{array}{r}85 \\
-5\end{array}$ & $\begin{array}{r}32 \\
+8\end{array}$ & $\begin{array}{r}665 \\
-43\end{array}$ & $\begin{array}{r}110 \\
+6\end{array}$ & $\begin{array}{r}718 \\
0\end{array}$ & $\begin{array}{r}515 \\
+3\end{array}$ \\
\hline$A B O$ & $\begin{array}{r}24 \\
1.4\end{array}$ & $\begin{array}{r}28 \\
0\end{array}$ & $\begin{array}{r}5 I \\
-3\end{array}$ & $\begin{array}{r}71 \\
+15\end{array}$ & $\begin{array}{r}27 \\
-1\end{array}$ & $\begin{array}{r}4 \mathrm{I} \\
-5\end{array}$ & $\begin{array}{r}3^{1} 3 \\
+7\end{array}$ & $\begin{array}{r}54 \\
+2\end{array}$ & $\begin{array}{r}402 \\
+16\end{array}$ & \\
\hline$M N S$ & $\begin{array}{r}3^{8} \\
-10\end{array}$ & $\begin{array}{r}3 I \\
-1\end{array}$ & $\begin{array}{r}62 \\
+6\end{array}$ & $\begin{array}{r}49 \\
+1\end{array}$ & $\begin{array}{r}65 \\
-5\end{array}$ & $\begin{array}{r}40 \\
-6\end{array}$ & $\begin{array}{r}481 \\
+27\end{array}$ & $\begin{array}{r}97 \\
-\quad 15\end{array}$ & & \\
\hline$P$ & $\begin{array}{r}5 \\
-3\end{array}$ & - & $\begin{array}{r}10 \\
+6\end{array}$ & $\begin{array}{r}20 \\
0\end{array}$ & $\begin{array}{r}6 \\
-2\end{array}$ & $\begin{array}{r}7 \\
-1\end{array}$ & $\begin{array}{r}95 \\
-\mathbf{I}\end{array}$ & & & \\
\hline$R h$ & $\begin{array}{r}19 \\
+1\end{array}$ & $\begin{array}{r}23 \\
+5\end{array}$ & $\begin{array}{r}59 \\
-5\end{array}$ & $\begin{array}{r}65 \\
+3\end{array}$ & $\begin{array}{r}66 \\
-12\end{array}$ & $\begin{array}{r}35 \\
-3\end{array}$ & & & & \\
\hline Lutheran & $\begin{array}{r}2 \\
-2\end{array}$ & $\begin{array}{r}3 \\
+1\end{array}$ & $\begin{array}{r}16 \\
-4\end{array}$ & $\begin{array}{l}4 \\
0\end{array}$ & - & & & & & \\
\hline Kell & $\begin{array}{r}4 \\
+2\end{array}$ & $\begin{array}{l}6 \\
0\end{array}$ & $\begin{array}{r}8 \\
-2\end{array}$ & $\begin{array}{r}10 \\
-2\end{array}$ & & & & & & \\
\hline Lewis & $\begin{array}{r}5 \\
3\end{array}$ & $\begin{array}{r}2 \\
+2\end{array}$ & $\begin{array}{r}18 \\
0\end{array}$ & & & & & & & \\
\hline Duffy & $\begin{array}{r}7 \\
-1\end{array}$ & $\begin{array}{r}3 \\
+3\end{array}$ & & & & & & & & \\
\hline Kidd & $\begin{array}{r}8 \\
+2\end{array}$ & & & & & & & & & \\
\hline
\end{tabular}

for $A B O$ and $M N$ by Landsteiner and Levine (1 $9^{28}$ ) and analysed by Wiener (1932), 13 I families analysed for $A B O$ and $M \mathcal{N}$ by Wiener and Vaisberg (1931), 66 families analysed for $A B O$ and $M \mathcal{N}$ by Zieve, Wiener and Fries (1936), 30 families tested for $A B O, M \mathcal{N}$, P.T.C. and sex by Boyd and Boyd (194I) and analysed by Finney (I94I) and 6o families tested for $A B O, M \mathcal{N}$ and $R h$ ( $R h$ positive and negative) by Landsteiner and Wiener (194I) and analysed, with 40 more families, by Wiener and Sonn (1943).

Mohr ( $195 \mathrm{I} a$ and $b$ ) has produced very strong evidence of linkage between the Lutheran genes and the Lewois genes. This was first detected by the sib method of Penrose (1946) and, after the testing of 17 complete families selected for possessing the antigen $L u^{a}$, it was shown too by the $u$ statistics. By neither method of analysis do our own families give any hint of the linkage, but this is one of the comparisons for which our information is slight.

That linkage between two genes is not detectable when "information" is adequate does not necessarily mean that they are not on the same chromosome, but it does mean that if they are on the same chromosome they must be so far apart that the linkage is not likely to be detected until a third gene is found within demonstrable linkage distance of both. Bearing this qualification in mind, it is clear from 
our results that none of the genes for the 9 blood group systems, or for P.T.C. tasting is partially sex-linked. It is also clear that the genes for $A B O, M \mathcal{N} S$ and $R h$ are not linked to each other or to the genes for $P$, Lutheran, Kell, Lewis, Duffy, Kidd or P.T.C. The information is somewhat inadequate in most of the remaining $2 \mathrm{I}$ of the 55 comparisons.

Acknowledgments. - The following past members of the Units have contributed to the work analysed in this paper: the late Dr G. L. Taylor, Director of the Galton Laboratory Serum Unit; Miss Aileen M. Prior (Mrs Dobson), Miss Elizabeth W. Ikin, Dr A. E. Mourant, Dr Sylvia D. Lawler and Mrs Doreen Bertinshaw.

\section{REFERENCES}

BOYD, W. C., AND BOYD, LYLE G. I 94 I. Data for testing for genetic linkage on 500 pairs of sibs. Ann. Eugen., Lond., II, I-9.

FINNEY, D. J. I940. The detection of linkage. Ann. Eugen., Lond., ro, I 7I-2 I4. FINNEY, D. J. I94I. The detection of linkage. II. Further mating types; scoring of Boyd's data. Ann. Eugen., Lond., I1, I0-30.

FISHER, R. A. I935a. The detection of linkage with "dominant" abnormalities. Ann. Eugen., Lond., 6, 187-201.

FISHER, R. A. I $935 b$. The detection of linkage with recessive abnormalities. Ann. Eugen., Lond., 6, 339-35I.

LANDSTEINER, K., AND LEVINE, P. 1928. On the inheritance of agglutinogens of human blood demonstrable by immune agglutinins. 7. exp. Med., 48, $73^{\mathrm{I}-749}$.

LANDSTEINER, K., AND WIENER, A. S. I94I. Studies on an agglutinogen $(R h)$ in human blood reacting with anti-rhesus sera and with human iso-antibodies. 7. exp. Med., 74, 309-320.

мOHR, J. I95 I $a$. A search for linkage between the Lutheran blood group and other hereditary characters. Acta path. scand., 28, 207-2 10.

монR, J. I $95 \mathrm{I} b$. Estimation of linkage between the Lutheran and the Lewis blood groups. Acta path. scand., 29, 339-344.

PENROSE, L. S. 1946. A further note on the sib-pair linkage method. Ann. Eugen., Lond., 13, 25-29.

WIENER, A.S. I932. Method of measuring linkage in human genetics; with special reference to blood groups. Genetics, 17, 335-350.

WIENer, A. S., AND SONN, EVE B. 1943. Heredity of the $R h$ factor. Genetics, 28, I57-I 6 I.

Wiener, A. S., And VAisberg, M. 193I. Heredity of the agglutinogens $M$ and $\mathcal{N}$ of Landsteiner and Levine. F. Immunol., 20, 371-388.

ZIEVYe, I., WIENER, A. S., AND FRIEs, J. r. I 936 . On the linkage relations of the genes for allergic disease and the genes determining the blood groups, $M \mathcal{N}$ types and eye colour in man. Ann. Eugen., Lond., 7, 163-1 78.

\section{References to blood group linkage studies not specifically mentioned in the present paper}

Bernstein, F. 1931. Zur Brumblegung der Chromosomentheoried der Vererbung beim Menschen mit besonderer Berucksichtung der Blutgruppen. Z. indukt. Abstamm. - $u$. VererbLehre, 57 , I I 3-1 38 .

BURKS, BARBARA S., AND WYANDT, HELEN. I94I. Oval blood cells in human subjects tested for linkage with taste for P.T.C., mid-digital hair, hair color, $A-B$ agglutinogens, and sex. Genetics, 26, 223-233.

HOGBEN, L., AND POLLACK, R. 1935. A contribution to the relation of the gene loci involved in the isoagglutinin reaction, taste blindness, Friedreich's ataxia and major brachydactyly of man. 3 . Genet., $3^{I}, 353-361$. 
KLOEPFER, H. W. 1946. An investigation of 171 possible linkage relationships in man. Ann. Eugen., Lond., 13, 35-71.

SNYDER, L. H. 194I. Studies in human inheritance. Xx. Four sets of alleles tested for incomplete sex linkage. Ohio 7 . Sci., $4^{1}, 89-92$.

SNYDER, L. H., BAXTER, R. C., AND KNISELY, A. W. 1941. Studies in human inheritance. XIx. The linkage relations of the blood groups, the blood types and taste deficiency to P.T.C. J. Hered., 32, 22-25. 